\title{
Effect of Hydrogen Ion-gradient on Carrier-mediated Transport of Glycylglycine across Brush Border Membrane Vesicles from Rabbit Small Intestine
}

\author{
Noriko Takuwa, ${ }^{1)}$ Tadahito Shimada, ${ }^{1,3)}$ Hisashi Matsumoto, ${ }^{1), 41}$ \\ Masayoshi HimukaI, ${ }^{2)}$ and Takeshi HosHI ${ }^{1)}$ \\ 1) Department of Physiology, Faculty of Medicine, University of \\ Tokyo, Bunkyo-ku, Tokyo, 113 Japan \\ ${ }^{2)}$ Division of Basic Nutrition, National Institute of Nutrition, \\ Shinjuku-ku, Tokyo, 162 Japan
}

\begin{abstract}
Glycylglycine (Gly-Gly) transport across rabbit small intestinal brush border membrane vesicles was studied in the presence and absence of $\mathrm{N} \mathrm{Na}^{+}$gradient or a $\mathrm{pH}$ gradient. The transport was found to be entirely independent of $\mathrm{Na}^{+}$but significantly stimulated by lowering extravesicular $\mathrm{pH}\left(\mathrm{pH}_{\mathrm{o}}\right)$. The maximum stimulation was seen at $\mathrm{pH}_{\mathrm{o}}$ 5.5, where the uptake rate was about 2-times higher than the control value. FCCP, a protonophore, abolished the stimulating effect of low $\mathrm{pH}_{\mathrm{o}}$, and low $\mathrm{pH}_{\mathrm{o}}$ conditions without a $\mathrm{pH}$ gradient did not stimulate the uptake rate. Overshoot uptake of Gly-Gly was observed when a $\mathrm{pH}$ gradient of $2 \mathrm{pH}$ units was imposed across the vesicular membrane. Valinomycin-induced inside-negative $\mathrm{K}^{+}$diffusion potential also had a stimulating effect on the uptake, and fluorescence measurements of vesicular suspensions containing $\mathrm{diS}_{-} \mathrm{C}_{3}-(5)$ revealed the occurrence of depolarization of the vesicular membranes when Gly-Gly was added to the suspensions. Kinetic study showed that a $\mathrm{pH}$ gradient caused a decrease of $K_{\mathrm{t}}$ for Gly-Gly without affecting $V_{\max }$. All the data obtained indicate that Gly-Gly transport is independent of $\mathrm{Na}^{+}$, dependent on $\mathrm{H}^{+}$gradient, and electrogenic, suggesting the mechanism of cotransport with $\mathrm{H}^{+}$.
\end{abstract}

Key words: dipeptide transport, $\mathrm{H}^{+}$-dependence, glycylglycine, $\mathrm{H}^{+}$coupled cotransport, intestinal brush border membrane, (rabbit intestine).

\footnotetext{
Received for publication March 27, 1985

3) Present address: 2nd Department of Internal Medicine, Faculty of Medicine, University of Tokyo, Bunkyo-ku, Tokyo, 113 Japan

4) Present address: 2nd Department of Internal Medicine, Osaka Medical College, Takatsuki, 569 Japan
} 
Newey and SMYTH $(1960,1962)$ first demonstrated the presence of cellular uptake of intact dipeptides from the luminal fluid followed by intracellular hydrolysis into amino acids during intestinal absorption of peptides. Subsequent studies by many other investigators have established that carrier-mediated transport of intact dipeptides and tripeptides across the apical membrane of intestinal epithelial cells is one of the important pathways of absorption of protein hydrolyzates (cf. reviews by MatTHEws, 1975; MAtThews and PAYNe, 1980; GANAPATHY and LEIBACH, 1982). In contrast to transport of other important nutrients, such as D-glucose and amino acids, apical membrane transport of dipeptides has been shown to be poorly dependent on, or entirely independent of, the presence of $\mathrm{Na}^{+}$ in the external medium (CheEseman and PARSONS, 1976; HimuKal et al., 1978, 1982, 1983; Himukai and Hoshi, 1980; GanaPathy et al., 1981; GaNaPATHY and LeibaCH, 1982, 1983; Berteloot et al., 1982). On the other hand, dipeptides added to the mucosal solution have been shown to induce cell membrane depolarization and a concomitant increase in membrane conductance in Necturus intestine in the absence of $\mathrm{Na}^{+}$in the medium (BoYD and WARD, 1982). HIMUKAI et al. (1983) have also shown that glycylglycine (Gly-Gly) added to the mucosal solution causes increments in short circuit current and transmural potential difference across isolated guinea pig ileum in the absence of $\mathrm{Na}^{+}$. These findings suggest that the dipeptide transport may involve interaction with a cation that is not $\mathrm{Na}^{+}$. Recently, Ganapathy and LeIBACH (1983) showed that transport of glycyl-L-proline and carnosine across intestinal and renal brush border membrane vesicles was not dependent on $\mathrm{Na}^{+}$but significantly stimulated by a $\mathrm{pH}$ gradient across the vesicular membrane. This suggests the possibility that hydrogen ion plays an important role in carrier-mediated transport of intact small peptides, probably through a cotransport mechanism. The present study was aimed at examining this possibility for Gly-Gly in rabbit intestinal brush border membrane vesicles.

\section{MATERIALS AND METHODS}

Preparation of brush border membrane vesicles. Intestinal brush border membrane vesicles (BBMVs) were prepared from rabbits weighing 2.2-2.4 kg according to the $\mathrm{Ca}^{2+}$-precipitation method (KESSLER et al., 1978). The original method was slightly modified in the present study. In brief, scraped mucosal tissues from the entire length of the small intestine were homogenized in a solution containing $100 \mathrm{~mm}$ mannitol and $10 \mathrm{~mm}$ Hepes/Tris (pH 7.5) using a Polytron-type homogenizer (Physcotron, Niti-on Co., Ltd., Japan). Usual serial procedures of the $\mathrm{Ca}^{2+}$-precipitation method, i.e. addition of $\mathrm{CaCl}_{2}$ to the homogenate to the final concentration of $10 \mathrm{~mm}$ and subsequent differential centrifugations, were repeated twice. The pellet obtained by the final differential centrifugation was washed

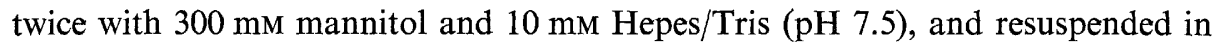


the same buffer solution at a protein concentration of about $10 \mathrm{mg} / \mathrm{ml}$. The suspensions were stored in liquid nitrogen until use. The specific activities of alkaline phosphatase and sucrase of the finally obtained preparations were found to have been enriched by a factor of around 20 .

Protein concentrations were measured by the method of BRADFORD (1976) using bovine serum albumin as a standard. Alkaline phosphatase and sucrase were assayed by the methods of BESSEY et al. (1946) and DAHLQVIST (1964), respectively.

Uptake experiments. Uptake of Gly-Gly by the membrane vesicles was measured at $25^{\circ} \mathrm{C}$ by the rapid filtration method as originally described by HoPFER et al. (1973) using $0.45 \mu \mathrm{m}$ pore-sized Millipore filters. Ten to $20 \mu 1$ of the vesicle suspension (the amount of protein $100-300 \mu \mathrm{g}$ ) was placed in a plastic tube kept at $25^{\circ} \mathrm{C}$ and, after $1 \mathrm{~min}, 100 \mu \mathrm{l}$ of uptake media kept at $25^{\circ} \mathrm{C}$ was added. After various time intervals, the reaction was stopped by the addition of $4 \mathrm{ml}$ of icecold stop solution and immediate filtering through a Millipore filter, followed by washing three times with $4 \mathrm{ml}$ stop solution. The time required for the washing procedure was less than $20 \mathrm{sec}$. The stop solution consisted of $150 \mathrm{~mm} \mathrm{KSCN}$ buffered to the same $\mathrm{pH}$ value as that of the uptake media with $1 \mathrm{~mm}$ of either Hepes/Tris or Mes/Hepes/Tris. Other specific conditions of incubation for each experiment are given in the figure explanations.

Measurements of transmembrane potential changes. A membrane potentialsensitive cyanine dye, 3,3'-dipropylthiodicarbocyanine iodide [diS- $\mathrm{C}_{3}-(5)$ ], was used for measurements of changes in transmembrane potential of the membrane vesicles, according to the procedure described by BECK and SACKTOR (1978). Fluorescence change was recorded with a Hitachi fluorospectrophotometer (Type 650-105) by setting excitation wave length at $622 \mathrm{~nm}$ and emission wave length at $670 \mathrm{~nm}$. The dye was added to the incubation medium in a cuvette as concentrated ethanol solutions to the final concentration of $2.0 \mu \mathrm{M}$. The concentration of ethanol did not exceed $0.5 \%$. The fluorescence data are given in arbitrary units.

Chemicals. Valinomycin and carbonly cyanide $p$-trifluoromethoxyphenylhydrazone (FCCP) were purchased from Sigma and Aldrich, respectively. [1$\left.{ }^{14} \mathrm{C}\right]$ Gly-Gly (custom made) was obtained from Amersham International. DiS$\mathrm{C}_{3}$-(5) was supplied by Nihon Kankoshikiso Kenkyusho (Japan Photosensitive Dye Institute, Okayama, Japan). All other chemicals were of reagent grade purity.

\section{RESULTS}

Effects of $\mathrm{Na}^{+}$gradient and extravesicular $\mathrm{pH}$ on Gly-Gly transport

At first, the $\mathrm{Na}^{+}$dependence of Gly-Gly transport was examined at different values of extravesicular $\mathrm{pH}\left(\mathrm{pH}_{\mathrm{o}}\right)$. Gly-Gly uptake by the membrane vesicles 


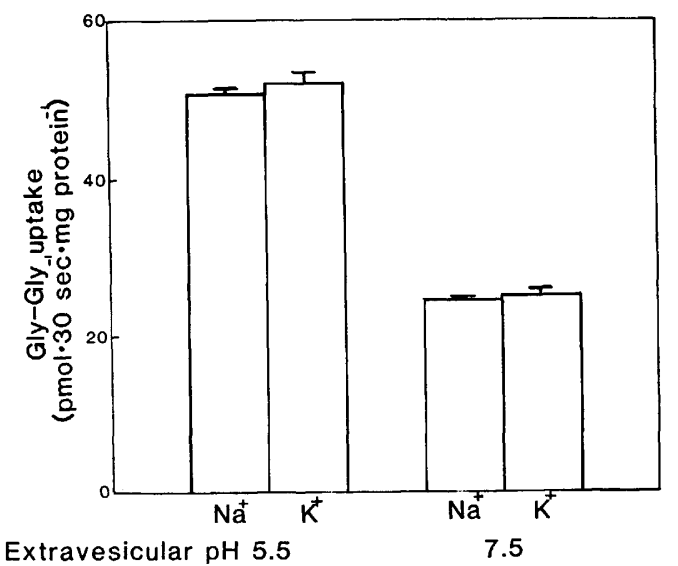

Fig. 1. Comparison of the rates of Gly-Gly uptake by BBMVs in the presence and absence of a $\mathrm{Na}^{+}$gradient at two different extravesicular $\mathrm{pH}$ values, 7.5 and 5.5. Gly-Gly uptake was measured during the initial $30 \mathrm{sec}$ of incubation in media containing $100 \mathrm{~mm}$ mannitol, $10 \mathrm{~mm}$ Hepes/Tris in cases of $\mathrm{pH}_{\circ} 7.5$ or $10 \mathrm{~mm}$ Mes/Hepes/Tris in cases of $\mathrm{pH}_{\circ}$ 5.5, $0.02 \mathrm{~mm}\left[1-{ }^{14} \mathrm{C}\right]$ Gly-Gly and either $100 \mathrm{~mm} \mathrm{NaSCN}$ or $100 \mathrm{~mm} \mathrm{KSCN}$. The letters $\mathrm{Na}^{+}$and $\mathrm{K}^{+}$at the bottom of the columns indicate the presence $\left(\mathrm{Na}^{+}\right)$and absence $\left(\mathrm{K}^{+}\right)$of the $\mathrm{Na}^{+}$gradient. A horizontal bar at the top of each column shows the positive value of the standard error (+S.E.) of mean.

during the initial $30 \mathrm{sec}$ was measured in the presence and absence of a $\mathrm{Na}^{+}$ gradient. $\mathrm{A} \mathrm{Na}^{+}$gradient was imposed by adding $\mathrm{NaSCN}$ to the incubation medium (extravesicular solution) to the final concentration of $100 \mathrm{mM}$. In the experiments without a $\mathrm{Na}^{+}$gradient, $100 \mathrm{~mm} \mathrm{KSCN}$ was added to the medium. At $\mathrm{pH}_{\mathrm{o}}$ 7.5, there was no statistically significant difference in the uptake rate between two different incubation conditions with regard to the $\mathrm{Na}^{+}$gradient (Fig. 1), confirming our previous observation in isolated guinea pig ileum (HimUKar et al., 1983). At a low $\mathrm{pH}_{0}$, e.g. 5.5, the uptake rate was found to increase markedly regardless of the presence of the $\mathrm{Na}^{+}$gradient. As compared with the rates at $\mathrm{pH}_{\mathrm{o}} 7.5$, the uptake rates at $\mathrm{pH}_{\mathrm{o}} 5.5$ were about two times higher. Again, no statistically significant difference was seen between the uptake rates in the presence and absence of the $\mathrm{Na}^{+}$gradient (Fig. 1). The results clearly indicate that GlyGly transport across the brush border membrane vesicles (BBMVs) is independent of $\mathrm{Na}^{+}$but stimulated by lowering external $\mathrm{pH}$. The maximum stimulation was seen at $\mathrm{pH}_{\circ} 5.5$ (Fig. 2).

\section{Effect of a $\mathrm{pH}$ gradient on Gly-Gly transport}

To clarify the nature of stimulatory effects of low $\mathrm{pH}_{0}$, two different types of experiments were carried out. One was to compare the uptake rates at a low $\mathrm{pH}_{\circ}$ in the presence and absence of a $\mathrm{pH}$ gradient across the vesicular membranes. In this series of experiments, the BBMVs were prepared at $\mathrm{pH} 7.5$ and equilibrated 


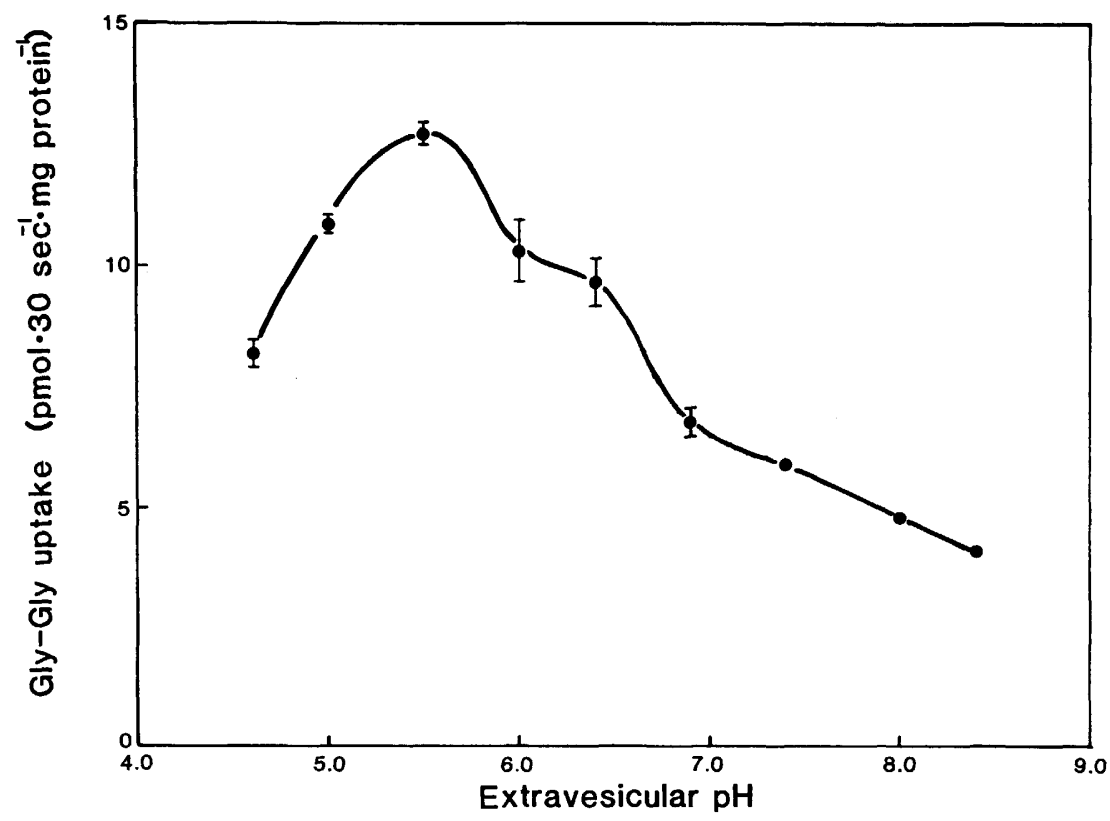

Fig. 2. Effect of extravesicular $\mathrm{pH}$ on the rate of Gly-Gly uptake as measured during the initial $30 \mathrm{sec}$. The transport was assayed in media containing $100 \mathrm{~mm}$ mannitol, $100 \mathrm{~mm}$ $\mathrm{KSCN}, 8 \mu \mathrm{M}\left[1-^{-14} \mathrm{C}\right] \mathrm{Gly}-\mathrm{Gly}$, and either $10 \mathrm{mM}$ Hepes/Tris (in cases of $\left.\mathrm{pH}_{\circ} 6.9-8.4\right)$ or $10 \mathrm{~mm}$ Mes/Hepes/Tris (in cases of $\mathrm{pH}_{0}$ 6.4-4.6). Each point shows the mean \pm S.E. of four determinations.

Table 1. Effect of transmembrane pH gradient on Gly-Gly uptake.

\begin{tabular}{cc}
\hline $\mathrm{pH}_{\mathrm{i}} / \mathrm{pH}_{\mathrm{o}}$ & Gly-Gly uptake $\left(\mathrm{pmol} \cdot 30 \mathrm{sec}^{-1} \cdot \mathrm{mg} \mathrm{protein}{ }^{-1}\right)$ \\
\hline $7.5 / 5.5$ & $257 \pm 6$ \\
$7.5 / 7.5$ & $207 \pm 7^{*}$ \\
$5.5 / 5.5$ & $123 \pm 6^{* *}$ \\
\hline
\end{tabular}

The membrane vesicles were preloaded with either $10 \mathrm{~mm}$ Hepes/Tris buffer $(\mathrm{pH}$ 7.5) or $10 \mathrm{~mm}$ Mes/Hepes/Tris buffer (pH 5.5), each containing $300 \mathrm{~mm}$ mannitol. The uptake solutions were composed of either $10 \mathrm{~mm} \mathrm{Mes/Hepes/Tris} \mathrm{buffer} \mathrm{(pH} \mathrm{5.5)} \mathrm{or} 10 \mathrm{~mm}$ Hepes/Tris buffer (pH 7.5), $100 \mathrm{~mm}$ mannitol, $100 \mathrm{~mm} \mathrm{KSCN}$, and $0.2 \mathrm{~mm}\left[11^{-14} \mathrm{C}\right]$ Gly-Gly. Data represent the mean \pm S.E. of three determinations. ${ }^{*} p<0.02,{ }^{* *} p<0.001$ (vs. control).

with buffer solutions of $\mathrm{pH} 7.5$ or 5.5 for $1 \mathrm{hr}$ at room temperature before the uptake experiments. The vesicular uptake of Gly-Gly was examined at $\mathrm{pH}_{\circ} 7.5$ or 5.5 in the absence of $\mathrm{Na}^{+}$. As shown in Table 1, significant stimulation was observed when the $\mathrm{pH}$ gradient was imposed. However, no stimulation was observed at a lowered $\mathrm{pH}$ value (5.5) where a $\mathrm{pH}$ gradient did not exist $\left(\mathrm{pH}_{\mathrm{o}}=\mathrm{pH}_{\mathrm{i}}=\right.$ 5.5). Another series of experiments examined the effect of a protonophore,

Vol. 35, No. 4, 1985 


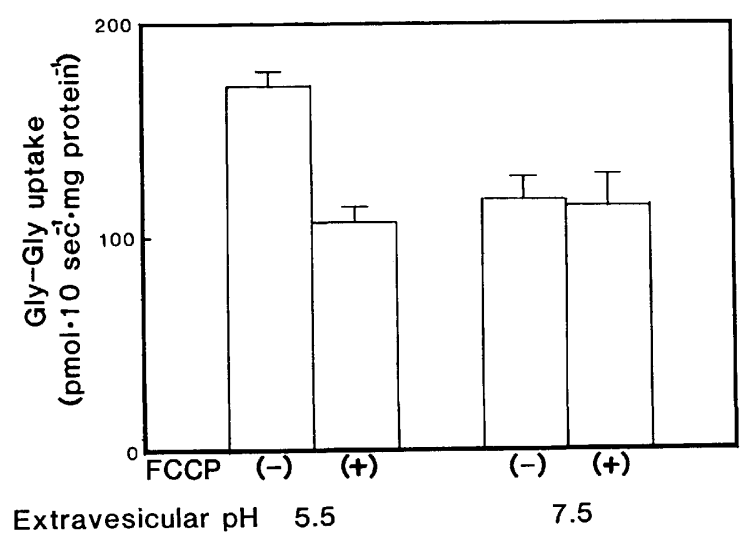

Fig. 3. Effects of FCCP on Gly-Gly uptake at two different $\mathrm{pH}_{\circ}$ (7.5 and 5.5). BBMVs were preincubated in a solution containing $300 \mathrm{~mm}$ mannitol, $10 \mathrm{~mm}$ Hepes/Tris $\mathrm{pH}$ 7.5), and either $50 \mu \mathrm{M}$ FCCP or $0.5 \%$ ethanol as control. The uptake media contained $100 \mathrm{~mm}$ mannitol, $100 \mathrm{~mm} \mathrm{KSCN}, 0.2 \mathrm{~mm}\left[1{ }^{-14} \mathrm{C}\right] \mathrm{Gly}$-Gly and either $10 \mathrm{~mm}$ Hepes/Tris (pH 7.5) or $10 \mathrm{~mm}$ Mes/Hepes/Tris (pH 5.5). The incubation time was $10 \mathrm{sec}$ in this series of experiments. A horizontal bar at the top of each column shows a positive value of the standard error of mean.

FCCP, on the uptake rate in the presence of a $\mathrm{pH}$ gradient $\left(\mathrm{pH}_{\mathrm{o}}<\mathrm{pH}_{\mathrm{i}}, 5.5<7.5\right)$. It was found that the presence of FCCP $(2 \mu \mathrm{M})$ almost completely abolished the stimulatory effect of the $\mathrm{pH}$ gradient imposed (Fig. 3). These results indicate that the stimulatory effect is not due to a low $\mathrm{pH}_{\mathrm{o}}$ per se, but the effect can be ascribed to a proton gradient down across the vesicular membranes.

Figure 4 shows the time courses of vesicular uptake of Gly-Gly in the presence and absence of a $\mathrm{pH}$ gradient. All measurements were made in the absence of $\mathrm{Na}^{+}$in the incubation media. As seen in this figure, the initial rate of uptake was significantly stimulated by an imposed $\mathrm{pH}$ gradient and transient overshoot uptake was seen when a $\mathrm{pH}$ gradient was present. Peak uptake occurred about $30 \mathrm{sec}$ after the start of incubation, after which the uptake value rapidly decreased toward a minimum value at about $2 \mathrm{~min}$. Thereafter, a slow gradual increase continued for more than $30 \mathrm{~min}$ in all experiments even in the absence of a $\mathrm{pH}$ gradient. Such a slow gradual increase has not been previously reported for $\mathrm{Na}^{+}$-dependent transport of D-glucose or amino acids. Therefore, this feature seemed characteristic of Gly-Gly. This may be related to intravesicular hydrolysis of Gly-Gly as discussed later.

The effect of the $\mathrm{pH}$ gradient on kinetics of Gly-Gly transport was studied over a range of Gly-Gly concentration from 12.5 to $0.2 \mathrm{~mm}$. Higher concentrations of Gly-Gly were also examined, but significant data could not be obtained because of larger scattering of data. This is probably due to relatively large passive influxes as compared with the mediated components at higher concentrations. Therefore, observations were limited to the changes in kinetic parameters caused 


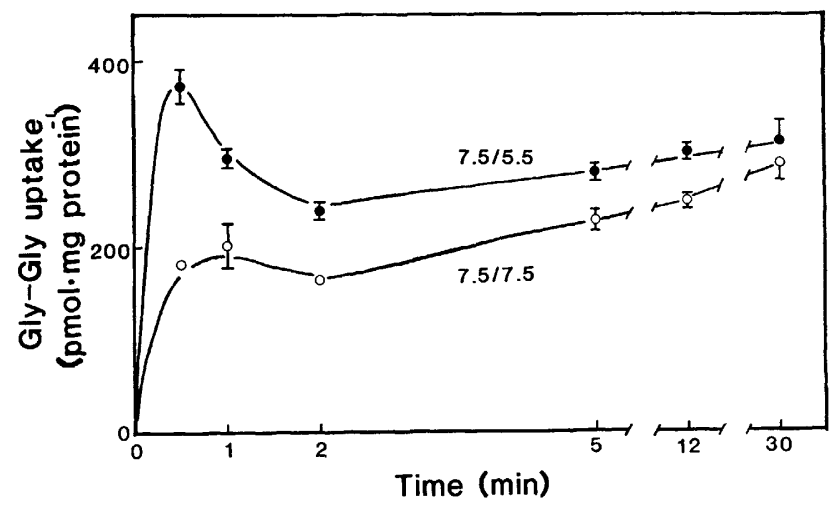

Fig. 4. Time courses of Gly-Gly uptake by BBMVs from $0.2 \mathrm{~mm}$ Gly-Gly solutions in the presence and absence of a $\mathrm{pH}$ gradient across the vesicular membranes $\left(\mathrm{pH}_{0}<\mathrm{pH}_{\mathrm{i}}\right)$. Incubation media contained $100 \mathrm{~mm}$ mannitol, $100 \mathrm{~mm} \mathrm{KSCN}, 0.2 \mathrm{~mm}\left[1-^{-14} \mathrm{C}\right] \mathrm{Gly}-\mathrm{Gly}$, and either $10 \mathrm{~mm}$ Mes/Hepes/Tris in the case of $\mathrm{pH}_{\mathrm{o}} 5.5(\bullet)$ or $10 \mathrm{~mm}$ Hepes/Tris in the case of $\mathrm{pH}_{\mathrm{o}} 7.5(\bigcirc)$. Each point represents the mean \pm S.E. of three determinations.

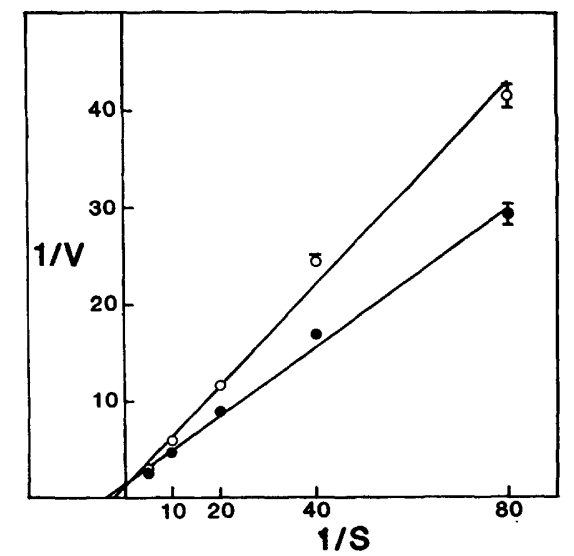

Fig. 5. Lineweaver-Burk type plot of kinetic data of Gly-Gly transport by BBMVs in the presence and absence of a proton gradient. Gly-Gly uptake was measured during the initial $10 \mathrm{sec}$ of incubation in media containing $100 \mathrm{mM} \mathrm{KSCN}, 90 \mathrm{~mm}$ mannitol, $20 \mathrm{~mm}$ of either Mes/Hepes/Tris (in cases of $\mathrm{pH}_{\mathrm{o}} 5.5, \bullet$ ) or Hepes/Tris (in cases of $\mathrm{pH}_{\mathrm{o}} 7.5,0$ ), and Gly-Gly at various concentrations. The uptake rate $(V)$ was expressed in $\mathrm{nmol} \cdot \mathrm{mg}$ protein ${ }^{-1} \cdot 10 \mathrm{sec}^{-1}$, and Gly-Gly concentration $(S)$ in mM. Each point represents the mean \pm S.E. of four determinations. The points without horizontal bars had a standard error smaller than the diameter of the circles.

by an imposed $\mathrm{pH}$ gradient. Lineweaver-Burk type plot of the data obtained gave straight lines in either the presence or absence of a $\mathrm{pH}$ gradient (Fig. 5), indicating the conformance of the transport to simple Michaelis-Menten kinetics regardless of the presence of a $\mathrm{pH}$ gradient. The presence of a proton gradient 
Table 2. Effect of valinomycin-induced inside-negative membrane potential on Gly-Gly uptake.

\begin{tabular}{cc}
\hline Valinomycin $(\mu \mathrm{M})$ & Gly-Gly uptake $\left(\mathrm{pmol}^{\circ} 30 \mathrm{sec}^{-1} \cdot \mathrm{mg} \mathrm{protein}{ }^{-1}\right)$ \\
\hline 0 & $356 \pm 10$ \\
10 & $475 \pm 9(p<0.005)$ \\
\hline
\end{tabular}

The membrane vesicles were preloaded with a solution containing $100 \mathrm{~mm} \mathrm{~K}_{2} \mathrm{SO}_{4}$, $100 \mathrm{~mm}$ mannitol, and $10 \mathrm{~mm}$ Hepes/Tris, $\mathrm{pH}$ 7.5. The uptake solutions were composed of $300 \mathrm{~mm}$ mannitol, $10 \mathrm{~mm} \mathrm{Mes} /$ Hepes/Tris (pH 5.5), $0.2 \mathrm{~mm}\left[1-^{-14} \mathrm{C}\right] \mathrm{Gly}-\mathrm{Gly}$, and either $10 \mu \mathrm{M}$ valinomycin or $0.5 \%$ ethanol (control). The data represent mean \pm S.E. of three determinations.

down across the membranes caused a decrease in $K_{\mathrm{t}}$ value for Gly-Gly without affecting the $V_{\max }$ value (Fig. 5). The $K_{\mathrm{t}}$ value decreased from $0.43 \mathrm{~mm}$ in control $\left(\mathrm{pH}_{\mathrm{o}}=\mathrm{pH}_{\mathrm{i}}=7.5\right)$ to $0.25 \mathrm{~mm}$ when a $\mathrm{pH}$ gradient $\left(\mathrm{pH}_{\mathrm{o}} 5.5\right.$ and $\left.\mathrm{pH}_{\mathrm{i}} 7.5\right)$ was imposed.

Effect of transmembrane potential and electrogenic property of Gly-Gly transport

In order to induce an inside-negative transmembrane potential, BBMVs were preloaded with $100 \mathrm{mM} \mathrm{K}_{2} \mathrm{SO}_{4}$ prior to use for uptake experiments. The suspension of the $\mathrm{K}^{+}$-loaded vesicles in a $100 \mathrm{mM} \mathrm{K}_{2} \mathrm{SO}_{4}$ solution was diluted with 10 times volume of a $\mathrm{K}^{+}$-free incubation medium which contained $10 \mu \mathrm{M}$ valinomycin. That valinomycin effectively induces inside-negative $\mathrm{K}^{+}$diffusion potential under such conditions was ascertained by measurements of fluorescence change using diS- $\mathrm{C}_{3}-(5)$ as described below. As shown in Table 2, valinomycin added to the incubation medium significantly stimulated the uptake in the presence of a $\mathrm{pH}$ gradient. The data suggest that Gly-Gly transport is electrogenic probably because of coupling with $\mathrm{H}^{+}$.

The electrogenic property of Gly-Gly transport was further ascertained by observing the changes in transmembrane potential induced by addition of Gly-Gly into the incubation medium. A membrane potential-sensitive cyanine dye, diS- $\mathrm{C}_{3}-$ (5), was used for this purpose. Figure 6 shows a representative trace of the fluorescence change induced by Gly-Gly. As a control, L-glucose, which is not transported by a carrier-mediated process in intestinal BBMVs, was added to the same concentration. As seen in this figure, a significant increase in fluorescence intensity occurred only when Gly-Gly was added. It was ascertained by observations of valinomycin-induced $\mathrm{K}^{+}$diffusion potential that the fluorescence increase corresponded to the depolarization of the transmembrane potential. Such a GlyGly induced fluorescence increase was reproducibly observed irrespective of the presence of $\mathrm{Na}^{+}$in the external medium. Also, the feature of fluorescence change was unchanged when $\mathrm{Na}^{+}$was totally replaced with $\mathrm{K}^{+}$, choline ${ }^{+}$, Tris ${ }^{+}$, or $\mathrm{Li}^{+}$. $\mathrm{D}$-Glucose was found to induce a similar fluorescence increase (membrane depolarization) only when $\mathrm{Na}^{+}$was present in the external medium (data not shown). 


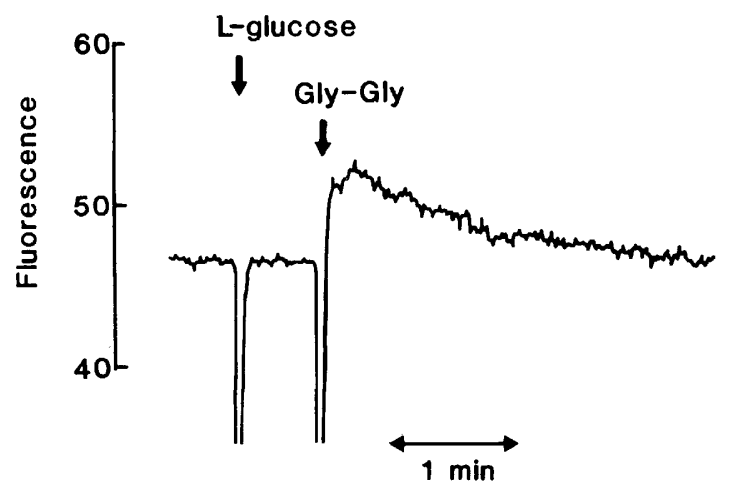

Fig. 6. Effect of Gly-Gly on transmembrane potential of BBMVs as monitored by fluorescence change of a membrane potential-sensitive dye, diS- $\mathrm{C}_{3}-(5)$. The membrane vesicles (protein amount $37.0 \mu \mathrm{g} / \mathrm{ml}$ ) were suspended in a solution containing $100 \mathrm{~mm}$ mannitol, $100 \mathrm{~mm}$ choline chloride, $1.8 \mathrm{~mm} \mathrm{CaCl}, 1.0 \mathrm{mM} \mathrm{MgCl}_{2}, 10 \mathrm{~mm}$ Hepes/Tris (pH 7.5), and $2 \mu \mathrm{M} \mathrm{diS}-\mathrm{C}_{3}-(5)$. The interruptions of the fluorometric trace indicate the addition of either $30 \mathrm{~mm}$ L-glucose or $20 \mathrm{~mm}$ Gly-Gly. A change of 10 arbitrary units represents a $21.5 \%$ change in the total fluorescence.

These findings indicate that Gly-Gly transport by rabbit intestinal BBMVs is electrogenic and associated with transfer of net positive charge probably carried by $\mathrm{H}^{+}$.

\section{DISCUSSION}

The results of the present study indicate that Gly-Gly transport across the brush border membrane of rabbit small intestine is independent of $\mathrm{Na}^{+}$, stimulated by an inward proton gradient, and electrogenic. The dependence on a proton gradient was ascertained by two different series of experiments, one to compare the uptake rates at a low $\mathrm{pH}_{\mathrm{o}}$ with and without a $\mathrm{pH}$ gradient and the other to examine the effect of a protonophore, FCCP, which rapidly dissipates $\mathrm{H}^{+}$gradient across biological and artificial lipid membranes (MITCHell, 1970). The electrogenic property was examined by observing the effect of valinomycin-induced inside-negative $\mathrm{K}^{+}$diffusion potential and Gly-Gly-induced fluorescence change by using a membrane potential-sensitive dye, diS- $\mathrm{C}_{3}-(5)$. All the data obtained support the hypothesis that Gly-Gly transport is dependent on an inward proton gradient and associated with transfer of net positive charge carried by a cation which is not $\mathrm{Na}^{+}$. These facts strongly suggest that Gly-Gly is transported with $\mathrm{H}^{+}$by a cotransport mechanism as suggested by GANAPATHY and LEIBACH (1983), and GANAPATHY et al. (1984) for glycyl-L-proline, L-carnosine, and glycylsarcosine.

If Gly-Gly is cotransported with $\mathrm{H}^{+}$, the presence of a sufficiently large proton gradient across the vesicular membranes should induce uphill transport of the dipeptide into the vesicles. This was also shown to be the case in the experiments 
in which the time course of vesicular uptake of Gly-Gly was examined in the presence and absence of the $\mathrm{pH}$ gradient of $2 \mathrm{pH}$ units. The peak uptake in the presence of the $\mathrm{pH}$ gradient, which occurred at about $30 \mathrm{sec}$ after the start of incubation, significantly exceeded the uptake values at 5 and $12 \mathrm{~min}$. However, because of the presence of a slow and continuous increase in the uptake, the peak value was only slightly higher than the value attained at $30 \mathrm{~min}$ when the equilibrium of Gly-Gly concentration seemed to have reached across the vesicular membranes. The reason for the occurrence of the slow and continuous increase is not clear at the present time. Such a slow increase in uptake is not usually observed for D-glucose and amino acids. Glycine-dipeptides are known to be hydrolyzed into constituent amino acids even within purified intestinal BBMVs probably by the activity of membrane-associated dipeptidase(s) (SIGRIST-Nelson, 1975; GANAPATHY and LEIBACH, 1982). Accordingly, accumulation of radioactive free glycine in addition to nonhydrolyzed Gly-Gly may be responsible for the slow continuous increase in uptake value that was measured with radioactive Gly-Gly. This means that the true equilibrated level of Gly-Gly may be somewhat lower than those estimated at 12 and $30 \mathrm{~min}$, and that the observed peak uptake in the presence of the $\mathrm{pH}$ gradient significantly exceeded the true equilibrated level. Recently, we demonstrated marked overshoot uptake of Gly-Gly in renal BBMVs in the simultaneous presence of a $\mathrm{pH}$ gradient and an inside-negative transmembrane potential (TAKUWA et al., 1985). The BBMVs used in that experiment were prepared by the $\mathrm{Mg} /$ EGTA method of BIBER et al. (1981), which has been shown to yield BBMVs less permeable to $\mathrm{H}^{+}$and other monovalent cations (SABOLIC and BurCKHARDT, 1984). This indicates that a proton gradient can drive uphill transport of dipeptides when a sufficiently large gradient is imposed across the brush border membranes.

Another important aspect of ion-coupled cotransport of nonelectrolytes is the increase in electrical conductance of the transporting membranes (HosHI and HIMUKAI, 1982; HoSHI, 1985). BOYD and WARD (1982) demonstrated that in Necturus intestinal cells, dipeptides added to the mucosal solution induced cell membrane depolarization and concomitant decrease in the input resistance. They also showed that these electrical changes were not dependent on the presence of $\mathrm{Na}^{+}$in the medium. Similar $\mathrm{Na}^{+}$-independent electrical changes were confirmed with Gly-Gly and L-carnosine in Triturus intestine in our laboratory, and, furthermore, it was observed that the changes in the transmembrane potential and conductance were augmented by lowering external $\mathrm{pH}$ (Shimada and Hoshi, unpublished observation). These findings also seem to corroborate the possible mechanism of $\mathrm{H}^{+}$-coupled cotransport of Gly-Gly and other dipeptides across the intestinal brush border membrane.

It is well known that intestinal and renal brush border membranes have many types of $\mathrm{Na}^{+}$-coupled cotransport carriers for physiologically important organic solutes and anions (Schultz and CurRan, 1970; Hoshi and HimukaI, 1982). 
The transport of a solute by a $\mathrm{Na}^{+}$-coupled carrier mechanism in animal cells is classified into the secondary active transport since electrochemical potential difference of $\mathrm{Na}^{+}$across the cell membranes effectively drives the uphill transport of the cotransported substrate, and the $\mathrm{Na}^{+}$electrochemical potential difference is maintained by the activity of the $\mathrm{Na}^{+}, \mathrm{K}^{+}$pump located in the cell membrane (Heinz, 1978; Schultz, 1978, 1980; Hoshi and HimukaI, 1982). The $\mathrm{Na}^{+}, \mathrm{K}^{+}$ pump is classified as primary active transport, since it converts chemical energy of ATP into its osmotic (and electrical) work directly. The coexistence of the $\mathrm{Na}^{+}$, $\mathrm{K}^{+}$pump and the $\mathrm{Na}^{+}$-coupled cotransport mechanism in the cell membranes enables the cells to transport a cotransported substrate in an uphill manner with high efficiency. For example, the $\mathrm{Na}^{+} / \mathrm{D}$-aldohexose cotransporters in the brush border membranes of the enterocytes can accumulate 3- $O$-methylglucose, a nonmetabolized hexose, within the cells about 70 -fold when the $\mathrm{Na}^{+}, \mathrm{K}^{+}$pump is intact and carrier-mediated exit of the sugar is blocked by cytochalacin B (KIMMICH and RANDLES, 1979). In the case of the $\mathrm{H}^{+}$-coupled cotransport, as demonstrated for Gly-Gly in the present study, a similar type of energy coupling cannot be considered since the primary active transport mechanism extruding $\mathrm{H}^{+}$ out of cells does not exist in the cell membrane.

Although extensive studies have not been made for intracellular $\mathrm{pH}$ in the enterocytes, the $\mathrm{pH}$ inside the cells has been reported to be nearly neutral $(\simeq 6.90)$ in the jejunum under normocapnia (KuRTIN and CHARNEY, 1984). On the other hand, the close vicinity of the brush border membrane of enterocytes is known to be significantly acidic compared to the bulk of the luminal fluid (LuCAs et al., 1975; LuCAS, 1984). Measurements of "microclimate $\mathrm{pH}$ " with $\mathrm{pH}$-microelectrodes revealed that the values of $\mathrm{pH}$ of the close vicinity of the proximal and middle jejunal cells were 5.9 and 6.0 , respectively, when the luminal bulk $\mathrm{pH}$ was $7.0-7.4$ (LuCAs et al., 1975). Also, such low microclimate $\mathrm{pH}$ has been shown to be dependent on the presence of $\mathrm{Na}^{+}$in the luminal fluid and intracellular metabolism (LuCAs, 1984). Accordingly, it seems reasonable to consider that a proton gradient large enough to drive uphill transfer of peptides is at least maintained across the brush border membranes of the proximal and middle jejunum nuder normal conditions. In regard to this, it is of interest to note that in coeliac and Crohn's diseases, the microclimate acidic pH is lost (LuCAs et al., 1978) and absorption of peptides is profoundly impaired (GANAPATHY and LEIBACH, 1985). This impairment can be interpreted, at least in part, as a result of diminution of the driving force for peptide transport. The $\mathrm{Na}^{+} / \mathrm{H}^{+}$antiport mechanism which has been shown to exist in the intestinal brush border membranes MURER et al., 1976; LIEDKE and HOPFER, 1982) is thought to be responsible for the maintenance of such a transmembrane proton gradient (GANAPATHY and LeIBACH, 1985). Accordingly, the $\mathrm{H}^{+}$-coupled cotransport of dipeptides may be regarded as a type of active transport which can be classified into the tertiary active transport since it depends on the $\mathrm{Na}^{+} / \mathrm{H}^{+}$antiport, a secondary active transport.

Vol. 35, No. 4, 1985 
The parallel existence of two different types of ion-coupled transport, the $\mathrm{Na}^{+}$coupled and $\mathrm{H}^{+}$-coupled mechanisms, in the brush border membrane seems to have a special physiological meaning. When multiple transport systems utilize a common driving force, heterologous inhibition of transport may occur due to competition of the common driving force (SEMEnZA, 1971). Protein hydrolyzates are important substrates to be absorbed by the small intestine under normal nutrition. Utilization of a different driving force, the proton gradient, by the peptide transport system may reduce or minimize such mutual inhibition of transport between peptides and other important nutrients, such as sugars and amino acids, during intestinal absorption after meal.

This work was supported by a Grant-in-Aid for Scientific Research from the Ministry of Education, Science and Culture of Japan. We wish to thank Ms. Ikuko Yamaguchi for preparing the manuscript.

\section{REFERENCES}

BeCK, J. C. and SACKTOR, B. (1978) Membrane potential-sensitive fluorescence changes during $\mathrm{Na}^{+}$-dependent D-glucose transport in renal brush border membrane vesicles. J. Biol. Chem., 253: 7158-7162.

Berteloot, A., Khan, A. H., and Ramaswamy, K. (1982) Characteristics of dipeptide transport in normal and papain-treated brush border membrane vesicles from mouse intestine. I. Uptake of glycyl-L-phenylalanine. Biochim. Biophys. Acta, 649: 179-188.

BesSeY, O. A., Lowry, O. H., and Brock, M. J. (1946) A method for the rapid determination of alkaline phosphatase with five cubic millimeters of serum. J. Biol. Chem., 164: 321-329.

Biber, J., Stieger, B., HaAse, W., and Murer, H.) (1981) A high yield preparation for rat kidney brush border membarnes. Different behaviour of lysosomal markers. Biochim. Biophys. Acta, 647: 169-176.

Boyd, C. A. R. and WARD, M. R. (1982) A micro-electrode study of oligopeptide absorption by the small intestinal epithelium of Necturus maculosus. J. Physiol. (Lond.), 324: 411428.

BRADFORD, M. M. (1976) A rapid and selective method for the quantitation of microgram quantities of protein utilizing the principle of protein-dye binding. Anal. Biochem., 72: 248254.

Cheeseman, C. I. and Parsons, D. S. (1976) The role of some small peptides in the transfer of amino nitrogen across the wall of vascularly perfused intestine. J. Physiol. (Lond.), 262: 459-476.

DAHLQvist, A. (1964) Method for assay of intestinal disaccharidases. Anal. Biochem., 7: $18-25$.

Ganapathy, V., Burckhardt, G., and Leibach, F. H. (1984) Characteristics of glycylsarcosine transport in rabbit intestinal brush border membrane vesicles. J. Biol. Chem., 259: 89548959.

Ganapathy, V. and Leibach, F. H. (1982) Peptide transport in intestinal and renal brush border membrane vesicles. Life Sci., 30: 2137-2146.

GaNAPATHY, V. and LeiBACH, F. H. (1983) Role of $\mathrm{pH}$ gradient and membrane potential in dipeptide transport in intestinal and renal brush-border membrane vesicles from the rabbit. Studies with L-carnosine and glycyl-L-proline. J. Biol. Chem., 258: 14189-14192. 
Ganapathy, V. and Leibach, F. H. (1985) Is intestinal peptide transport energized by a proton gradient? Am. J. Physiol., in press.

Ganapathy, V., Mendicino, J. F., and Leibach, F. H. (1981) Transport of glycyl-L-proline into intestinal and renal brush border membrane vesicles from rabbit. J. Biol. Chem., 256: 118-124.

HeInz, E. (1978) Mechanisms and Energetics of Biological Transport, Springer-Verlag, Berlin/ Heidelberg.

HimukaI, M. and Hoshi, T. (1980) Mechanisms of glycyl-L-leucine uptake by guinea-pig small intestine: Relative importance of intact-peptide transport. J. Physiol. (Lond.), 302: 155169.

Himukat, M., Kameyama, A., and Hoshi, T. (1983) Interaction of glycylglycine and $\mathrm{Na}^{+}$at the mucosal border of guinea-pig small intestine. A non-mutual stimulation of transport. Biochim. Biophys. Acta, 732: 659-667.

Himukai, M., Kano-Kameyama, A., and Hoshi, T. (1982) Mechanisms of inhibition of glycylglycine transport by glycyl-L-leucine and L-leucine in guinea pig small intestine. Biochim. Biophys. Acta, 687: 170-178.

HimukaI, M., Suzuki, Y., and Hoshi, T. (1978) Differences in characteristics between glycine and glycylglycine transport in guinea pig small intestine. Jpn. J. Physiol., 28: 499-510.

Hopfer, U., Nelson, K., Perrotto, J., and Isselbacher, K. J. (1973) Glucose transport in isolated brush border membrane from rat small intestine. J. Biol. Chem., 248: 25-32.

HosHI, T. (1985) Proton-coupled transport of organic solutes in animal cell membranes and its relation to $\mathrm{Na}^{+}$transport. Jpn. J. Physiol., 35: 179-191.

HosHi, T. and HimukaI, M. (1982) $\mathrm{Na}^{+}$-coupled transport of organic solutes in animal cells. In: Transport and Bioenergetics in Biomembranes, ed by SATO, R. and KAGAWA, Y., Japan Scientific Societies Press, Tokyo; Plenum Press, New York/London, pp. 111-135.

Kessler, M., Acuto, O., Storelli, C., Murer, H., Muller, M., and Semenza, G. (1978) A modified procedure for the rapid preparation of efficiently transporting vesicles from small intestinal brush border membranes. Their use in investigating some properties of Dglucose and choline transport systems. Biochim. Biophys. Acta, 506: 136-154.

Кiмmich, G. A. and RANDLEs, J. (1979) Energetics of sugar transport by isolated intestinal epithelial cells: Effects of cytochalacin B. Am. J. Physiol., 237: C56-C63.

Kurtin, P. and Charney, A. N. (1984) Intestinal ion transport and intracellular pH during acute respiratory alkalosis and acidosis. Am. J. Physiol., 247: G24-G31.

LIEDKE, C. M. and Hopfer, U. (1982) Mechanism of $\mathrm{Cl}^{-}$translocation across small intestinal brush border membrane. I. Absence of $\mathrm{Na}^{+}-\mathrm{Cl}^{-}$cotransport. Am. J. Physiol., 242: G263-G271.

LuCAS, M. L. (1984) The surface $\mathrm{pH}$ of the intestinal mucosa and its significance in the permeability of organic anions. In: Pharmacology of Intestinal Permeation I, ed. by CsákY, T. Z., Springer-Verlag, Berlin/Heidelberg/New York/Tokyo, pp. 119--163.

Lucas, M. L., Cooper, B. T., Lei, F. H., Johnson, I. T., Holmes, G. K. T., Blair, J. A., and COOKE, W. T. (1978) Acidic microclimate in coeliac and Crohn's disease. A model for folate malabsorption. Gut, 19: 735-742.

Lucas, M. L., Schneider, W., Haberich, F. J., and Blair, J. A. (1975) Direct measurement by $\mathrm{pH}$-microelectrode of the $\mathrm{pH}$ microclimate in rat proximal jejunum. Proc. R. Soc. Lond. Biol., 192: 39-48.

Matthews, D. M. (1975) Intestinal absorption of peptides. Physiol. Rev., 55: 537-608.

Matthews, D. M. and PAYNe, J. W. (1980) Transmembrane transport of small peptides. In: Current Topics in Membranes and Transport, ed. by Bronner, F. and Kleinzeller, A., Academic Press, New York, Vol. 14, pp. 331-425.

MitcheLl, P. (1970) Reversible coupling between transport and chemical reactions. In:

Vol. 35, No. 4, 1985 
Membrane and Ion Transport, ed. by BitTer, E., Wiley-Interscience, London/New York/ Sydney, Vol. 1, pp. 192-256.

Murer, H., Hopfer, U., and KINNE, R. (1976) Sodium/proton antiport in brush border membrane vesicles isolated from rat small intestine and kidney. Biochem. J., 154: 597-604.

NeweY, H. and Smyth, D. H. (1960) Intracellular hydrolysis of dipeptides during intestinal absorption. J. Physiol. (Lond.), 152: 367-380.

NeWEY, H. and SMYTH, D. H. (1962) Cellular mechanisms in intestinal transfer of amino acids. J. Physiol. (Lond.), 164: 527-551.

SABolic, J. and Burckhardt, G. (1984) Effect of the preparation method on $\mathrm{Na}^{+}-\mathrm{H}^{+}$exchange and ion permeabilities in rat renal brush border membranes. Biochim. Biophys. Acta, 772: 140-148.

Schultz, S. G. (1978) Ion-coupled transport across biological membranes. In: Physiology of Membrane Diseases, ed. by Andreoli, T. E., Hoffman, J. F., and Fanestil, D. D., Plenum Medical Book Co., New York/London, pp. 273-286.

Schultz, S. G. (1980) Basic Principles of Membrane Transport. Cambridge University Press, Cambridge.

Schultz, S. G. and Curran, P. F. (1970) Coupled transport of sodium and organic solute. Physiol. Rev., 50: 637-718.

SEMENZA, G. (1971) On the mechanism of mutual inhibition among sodium-dependent transport systems in the small intestine. A hypothesis. Biochim. Biophys. Acta, 241: 637-649.

SigRIST-NELSON, K. (1975) Dipeptide transport in isolated intestinal brush border membrane. Biochim. Biophys. Acta, 394: 220-226.

Takuwa, N., Shimada, T., Matsumoto, H., and Hoshi, T. (1985) Proton-coupled transport of glycylglycine in rabbit renal brush border membrane vesicles. Biochim. Biophys. Acta, 814: $186-190$. 